\title{
The protective effect of Crataegus monogyna Jacq aqueous extract (fruits and leaves) on blood cells and lipid profile of rats after copper induced-toxicity
}

\author{
Feriel Remita*, Cherif Abdennour, Amina Talbi and Kamel Khelili \\ Laboratory of Animal Ecophysiology, Department of Biology, Faculty of Sciences, \\ University Badji Mokhtar-Annaba, Annaba 23000, Algeria \\ *Email: remitaferiel@gmail.com
}

Received : 21.02.2021; Revised : 12.03.2021; Accepted : 15.03.2021

\begin{abstract}
The objective of this work is to use the Hawthorn Crataegus monogyna, as a protective agent against copper chronic intoxication. Male Wistar rats were divided into six groups; the control received tap water, standard diet ad libitum, two positive controls treated respectively with Hawthorn leaves and fruits aqueous extract, a group treated with $\mathrm{Cu}$ and finally, two groups treated with $\mathrm{Cu}$ +leaves $(\mathrm{CuL})$ and $\mathrm{Cu}+$ fruits $(\mathrm{CuF})$. The treatment was done by gavage for 30 consecutive days, where: glucose-6-phosphate of erythrocytes (G6PD), white blood cells (WBC), red blood cells (RBC), platelets (PLT), hemoglobin (HGB), hematocrits (HCT), mean corpuscular volume (MCV), triglycerides (TRIG), cholesterol (CHOL), high density lipoproteins (HDL) and low density lipoproteins (LDL) were measured. Copper treatment reduced G6PD, RBC, HGB, HCT, MCV, TRIG and CHOL levels, compared to the control. Compared to the Cu group, the two combined treatments ( $\mathrm{Cu} L$ and $\mathrm{Cu} F$ ) have an increase on G6PDH, RBC, HGB, HCT, MCV, TRIG and CHOL levels, with a decrease in WBC, PLT, and LDL levels. As a conclusion, hawthorn aqueous extracts have mitigated copper toxicity towards blood cells and LDL of wistar rats.
\end{abstract}

Keywords : Glucose-6-Phosphate Dehydrogenase, hawthorn, high density lipoprotein, red blood cells

\section{INTRODUCTION}

Copper is a trace element essential for many biological processes, but it becomes harmful when it exceeds the threshold level (Abbas et al., 2018). About $60 \%$ of consumed copper is absorbed in the stomach and the small intestine (DES, 2013), where its absorption, distribution, detoxification and elimination are well controlled (Kumar et al., 2015). Copper homeostasis maintains of copper distribution and prevents causing any negative effects to cellular defense system (Quamar et al., 2019). However, both augmentation and deficiency of copper concentration may cause physiological disorders (Chambers et al., 2010). Thus, increases in copper concentration in body have been reported to be associated with many pathological conditions (Parmar et al., 2002; Ozcelik and Uzun, 2009) as anemia by the red blood destruction (DES, 2013), abnormal lipid profile (Burkhead and Lutsenko, 2013) and lower triglycerides concentrations (Wuolikainen et al., 2014). Furthermore, high copper level provokes cell injury (Saravu et al., 2007) by oxidizing cell membranes (James et al., 1999; Saravu et al., 2007), mitochondrial dysfunction and lowering antioxidant enzymes, leading to oxidative stress damage (Tiwari et al., 2018).

Through the years, interest of using plant compounds has been growing faster in worldwide due to their benefits on health (Nandi and Ghosh, 2016). Hawthorn, Crataegus monogyna, is one of very common shrub plant used in medicinal treatments (Fong and Bauman, 2002), which considered a relatively safe herb and without serious adverse effects (Zapfe, 2001). The plant is well distributed in the Mediterranean region. $C$. monogyna is rich in proanthocyanidins and flavonoids (Bahorun et al., 1996), which are superoxide anion (Keser et al., 2014), hydroxyl radical, hydrogen peroxides scavengers and lipid peroxidase reducer (Bahorun et al., 1994 ; RiceEvans, 2004), which make it a powerful antioxidant (Yao et al., 2008). Interestingly, flavonoids of Hawthorn have the ability to inhibit copper intake (Kuo et al., 1998).

The aim of this study is to investigate the ability of the common C.monogyna aqueous extract of both fruits and leaves in protecting blood 
biomarkers and lipid profile of Wistar rat intoxicated with copper sulfate.

\section{MATERIALS AND METHODS}

\section{Plant and preparation}

Crataegus monogyna is grown spontaneously along the Algeria northern zone, exceeding 3 meters in length, and characterized by green leaves, white flowers and red fruits; the latter reaches maturity in mid-autumn. Fruits and leaves were harvested freshly in November from Annaba area, northeastern Algeria. $1.5 \mathrm{~g} / \mathrm{kg}$ bwe of fruits $(\mathrm{F})$ and leaves (L) were weighted daily, crushed in an appropriate volume of distilled water (where each rat takes $1 \mathrm{ml}$ of the obtained extract) and were kept overnight at room temperature. The two homogenates were filtered in the morning for obtaining the of $\mathrm{F}$ and $\mathrm{L}$ aqueous extract. Copper sulfate powder was dissolved daily directly before carrying out the tests in distilled water. The mixture of copper $+\mathrm{F}$ and copper $+\mathrm{L}$ where prepared daily using the same doses.

\section{Experimental design}

Wistar rats were purchased from the Pasteur institute, Algiers (Algeria) weighing $196 \pm 8 \mathrm{~g}$, that received tap water and standard diet ad libitum. Thirty-six males were divided equally into 6 groups; the control (C) having a standard diet, the copper (Cu: $100 \mathrm{mg} \mathrm{CuSO}_{4} \cdot 5 \mathrm{H}_{2} \mathrm{O} / \mathrm{Kg} \mathrm{bw}$ ), the fruits ( $\mathrm{F}: 1.5 \mathrm{~g}$ fruits $/ \mathrm{kg} \mathrm{bw}$ ), the leaves (L: $1.5 \mathrm{~g}$ leaves/ $\mathrm{kg} \mathrm{bw})$, the $\mathrm{Cu}+\mathrm{F}\left(100 \mathrm{mg} \mathrm{CuSO}{ }_{4} .5 \mathrm{H}_{2} \mathrm{O} / \mathrm{Kg}\right.$ bw + $1.5 \mathrm{~g}$ fruits $/ \mathrm{kg} \mathrm{bw})$ and the $\mathrm{Cu}+\mathrm{L}(100 \mathrm{mg}$ $\mathrm{CuSO}_{4} \cdot 5 \mathrm{H}_{2} \mathrm{O} / \mathrm{Kg} \mathrm{bw}+1.5 \mathrm{~g}$ leaves $/ \mathrm{kg} \mathrm{bw}$ ) group. Rats were sacrificed by decapitation after 30 consecutive days of copper oral administration, fruits and leaves solutions. Blood was collected in heparinized and EDTA test tubes, in which heparinized tubes were centrifuged at $3000 \mathrm{rpm}$ for 10 minutes, and then the plasma was stored at $20^{\circ} \mathrm{C}$ till further analysis. Animals' experiments were authorized by the Ethical Committee of Animal Sciences at the University at the Badji Mokhtar university of Annaba (Algeria).

\section{Erythrocytes G6PD assay}

Glucose-6-phosphate deshydrogenase (G6PD) dosage was measured using Mindray BS-380 apparatus, according to BIOLABO REAGENT
(U.V Kineticmethod) kit and the reaction scheme (Beutler et al., 1977). The rate of increase in $\mathrm{NADPH}$ concentration measured at $340 \mathrm{~nm}$ is proportional to the G6PD activity of the specimen.

\section{Complete blood count}

The complete blood count was realized by using the blood counter Abacus 4.

\section{Triglycerides assay}

Triglyceride has been assayed using the enzymatic colorimetric method; according to the technical user manual of the Spinreact Kit (Spain). The triglycerides incubated with lipoprotein lipase (LPL) release the glycerol and free fatty acids. Glycerol is converted to glycerol-3-phosphat (G3P) and adenosine-5-diphosphate (ADP), by the glycerol kinase and adenosine phosphate (ATP). The G3P is then converted by the glycerol phosphate dehydrogenase (GPO) in active ingredient to dihydroxyacetone phosphate (DAP) and hydrogen peroxidase $\left(\mathrm{H}_{2} \mathrm{O}_{2}\right)$. The latter reacts with 4-aminophenazone (4-AP) and p-chlorophenol in the presence of peroxidase (POD) to give a red color (Bucolo and David 1973).

\section{HDL Cholesterol assay}

The dosage of high density lipoproteins HDL has been carried out by the enzymatic method (Spinreact Kit, Spain).The very low density (VLDL) and low density (LDL) lipoproteins were precipitated by phosphotungstate in the presence of magnesium ions. After centrifugation the supernatant contains high density lipoproteins (HDL). The HDL cholesterol fraction was determined using the total cholesterol enzymatic reagent (Naito, 1984; Grove, 1979).

\section{LDL cholesterol assay}

The dosage of low density lipoproteins (LDL) was assayed according to technical guide of Spinreact Kit, Spain. Direct determination of serum LDL (low-density lipoprotein cholesterol) levels was carried out without the need for any sample pre-treatment or centrifugation of the sample (Friedewald et al., 1972).

\section{Cholesterol assay}

The assay of high density lipoproteins (HDL) was realized by the enzymatic method according 
to the technical data sheet of the Spinreact Kit, Spain (Naito, 1984).

\section{RESULTS AND DISCUSSION}

Hematological markers are presented in table 1 showed a significant decrease in $\mathrm{Cu}$ group in G6PD, RBC, HGB and HCT levels, contrary $\mathrm{Cu}$ has augmented the WBC, PLT and MCV levels compared to the control. No change in the group treated with $\mathrm{Cu} F$, while $\mathrm{Cu} \mathrm{L}$ group showed a significant increase in G6PD, RBC, HCT and MCV levels, and a significant decrease in WBC level compared to the control.

Table 2 represents the rat's lipid profile exposed to copper for one month. Our Results showed significant decreases in triglyceride and cholesterol, while HDL and LDL levels kept the same levels compared to the control. $\mathrm{Cu} F$ showed an augmentation in triglyceride, cholesterol and decreased the HDL and LDL levels compared to the $\mathrm{Cu}$ group. In the group treated with $\mathrm{Cu} \mathrm{L}$, triglyceride, cholesterol and HDL levels augmented significantly, while no change was observed in LDL level compared to the $\mathrm{Cu}$ group.
In this research, copper sulfate administrated to rat for one month decreased significantly the G6PD, RBC, HGB and HCT levels, while it increased WBC, PLT and MCV. Recently, high copper level decreased the RBC counts and HGB concentration in rats (Akomolafe et al., 2014) as a result of erythrocytes hemolysis induced by the free copper ions. The low activity of G6PD in rats of the copper group might be related to the inhibition of the enzyme by copper ions, an enzyme responsible of the red cells protection from oxidative stress by maintaining the GSH level through NADPH generation (Joshi et al., 2002). Moreover, toxic copper was reported to induce hemolysis, leading to red blood dysfunction (Savaru et al., 2007), and disturbs the erythropoiesis by affecting iron metabolism in the intestinal tracts, where copper and iron are antagonists (Pmila et al., 1991). The observed iron deficiency during high copper level has led to anemia (Eck and Wilson, 1989) and methaemoglobinaemia (Oldenquist and Salem, 1999; Ahasan et al., 1994), which confirm that copper is involved in the erythropoiesis process (Samanta et al., 2011). On the other hand, the MCV

Table 1: Mean \pm SD of some hematological markers in the different groups after treatments by copper sulphate and $C$. monogyna for one month.

\begin{tabular}{|c|c|c|c|c|c|c|}
\hline & Control & $\mathrm{Cu}$ & $\mathbf{F}$ & $\mathbf{L}$ & $\mathrm{Cu} \mathbf{F}$ & Cu L \\
\hline G6PD (mUI/10^9) & $121.4 \pm 0.9^{b}$ & $83.3 \pm 0.6^{\mathrm{d}}$ & $124.1 \pm 0.8^{\mathrm{a}}$ & $121.1 \pm 2^{\mathrm{b}}$ & $121 \pm 0.6^{\mathrm{b}}$ & $101 \pm 0.4^{\mathrm{c}}$ \\
\hline WBC $\left(10^{3} / \mathrm{mm}\right)$ & $7.49 \pm 0.35^{\mathrm{c}}$ & $12.04 \pm 0.1^{\mathrm{a}}$ & $7.95 \pm 0.8^{\mathrm{c}}$ & $7.87 \pm 0.7^{\mathrm{c}}$ & $8.01 \pm 0.9^{c}$ & $9.87 \pm 0.4^{b}$ \\
\hline $\operatorname{RBC}\left(10^{6} / \mathrm{mm}^{3}\right)$ & $10.36 \pm 0.3^{\mathrm{a}}$ & $8.22 \pm 0.2^{\mathrm{e}}$ & $9.86 \pm 0.4^{\mathrm{bc}}$ & $9.47 \pm 0.2^{\mathrm{cd}}$ & $10.05 \pm 0.03^{\mathrm{ab}}$ & $9.017 \pm 0.06^{\mathrm{d}}$ \\
\hline PLT $\left(10^{3} / \mathrm{mm}^{3}\right)$ & $317 \pm 1.7^{\mathrm{c}}$ & $899 \pm 2.4^{\mathrm{a}}$ & $316 \pm 20.9^{c}$ & $307 \pm 8.1^{\mathrm{c}}$ & $305 \pm 5.8^{\mathrm{c}}$ & $435 \pm 30.4^{b}$ \\
\hline $\operatorname{HGB}(\mathrm{g} / \mathrm{L})$ & $151.8 \pm 5.04^{\mathrm{a}}$ & $133.8 \pm 3.4^{\mathrm{c}}$ & $152 \pm 3.6^{\mathrm{a}}$ & $152 \pm 2.1^{\mathrm{a}}$ & $152 \pm 0.8^{\mathrm{a}}$ & $144.6 \pm 0.8^{\mathrm{b}}$ \\
\hline HCT (\%) & $51.04 \pm 0.8^{\mathrm{b}}$ & $40.7 \pm 0.7^{\mathrm{d}}$ & $52.4 \pm 0.8^{\mathrm{a}}$ & $50.7 \pm 0.7^{b}$ & $50.4 \pm 0.5^{b}$ & $47.3 \pm 0.8^{\mathrm{c}}$ \\
\hline $\operatorname{MCV}$ (fI) & $51.6 \pm 0.5^{\mathrm{a}}$ & $39.3 \pm 0.8^{c}$ & $51.1 \pm 0.7^{\mathrm{a}}$ & $51 \pm 0.6^{\mathrm{a}}$ & $51 \pm 0.6^{\mathrm{a}}$ & $47.8 \pm 0.7^{\mathrm{b}}$ \\
\hline
\end{tabular}

Means that do not share the same letter are significantly different $(\mathrm{p}<0.05)$, according to one-way ANOVA, followed by Tukey test. G6PD: 6-phosphate; WBC: white blood cells; RBC: red blood cells; PLT: platelets, HGB: hemoglobin; HCT: hematocrits; MCV: mean corpuscular volume.

Table 2: Mean \pm SD of Biochemical markers in the different groups after treatments by copper sulphate and $C$. monogyna for one month.

\begin{tabular}{lcccccc}
\hline & Control & $\mathbf{C u}$ & $\mathbf{F}$ & $\mathbf{L}$ & $\mathbf{C u} \mathbf{F}$ & $\mathbf{C u ~ L}$ \\
\hline TRIG (g/l) & $0.88 \pm 0.07^{\mathrm{a}}$ & $0.13 \pm 0.03^{\mathrm{d}}$ & $0.56 \pm 0.02^{\mathrm{c}}$ & $0.63 \pm 0.03^{\mathrm{b}}$ & $0.55 \pm 0.03^{\mathrm{c}}$ & $0.55 \pm 0.03^{\mathrm{c}}$ \\
CHOL (g/l) & $0.68 \pm 0.007^{\mathrm{a}}$ & $0.21 \pm 0.01^{\mathrm{c}}$ & $0.46 \pm 0.01^{\mathrm{c}}$ & $0.53 \pm 0.02^{\mathrm{b}}$ & $0.54 \pm 0.02^{\mathrm{b}}$ & $0.55 \pm 0.01^{\mathrm{b}}$ \\
HDL (g/l) & $0.31 \pm 0.01^{\mathrm{e}}$ & $0.31 \pm 0.01^{\mathrm{e}}$ & $0.56 \pm 0.008^{\mathrm{a}}$ & $0.45 \pm 0.007^{\mathrm{b}}$ & $0.37 \pm 0.01^{\mathrm{c}}$ & $0.33 \pm 0.008^{\mathrm{d}}$ \\
LDL (g/l) & $0.18 \pm 0.008^{\mathrm{a}}$ & $0.17 \pm 0.01^{\mathrm{ab}}$ & $0.10 \pm 0.005^{\mathrm{c}}$ & $0.09 \pm 0.001^{\mathrm{c}}$ & $0.11 \pm 0.01^{\mathrm{c}}$ & $0.15 \pm 0.01^{\mathrm{b}}$ \\
\hline
\end{tabular}

Means that do not share the same letter are significantly different $(\mathrm{p}<0.05)$, according to one-way ANOVA, followed by Tukey test. TRIG: triglycerides; CHOL: cholesterol, HDL: high density lipoproteins; LDL: low density lipoproteins. 
and HCT level have increased significantly when rats exposed to copper, without affecting $\mathrm{RBC}$ count and HBG concentration (Akomolafe et al., 2016). Liver injury by the copper toxicos is may lead to coagulation cascade (Nelson, 2002); this perhaps explains the observed rise in PLT levels in our finding, which was not the case in the study of Ganong, (2009) who reported that high copper charge had decreased the PLT level by inhibiting the thrombopoietin production. Copper may cause inflammatory reactions to some organs such as liver, heart and kidneys, which may explain the increase of WBC as the macrophages that are sensitive to heavy metals toxicity (Witeska and Wakulska, 2007).

The combined treatment of copper and hawthorn fruits extract in this study showed an increase in G6PD activity and HCT levels, without affecting the other parameters. Thus, C. monogyna seems to play an important role in free radicals scavenging induced by copper sulphate, as the study of Bernatonienë et al. (2008), who indicated that aqueous and ethanolic extracts have the capacity in protecting cells from oxidative stress. Moreover, hawthorn was reported to be rich in polyphenols (Liu et al., 2019), that have protective activity for hematological markers against lead toxicity (Aksu et al., 2012). Also, the active compounds in $C$. monogyna seem to have the ability to enhance the antioxidant system by rising G6PD activity to protect red blood cells against stress injuries. This enzyme is the main supplier of protons through the coenzyme NADP to generate reduced glutathione.

The remarkable triglycerides and cholesterol concentrations decrease in rats having toxic copper dose after thirty days consecutive exposure were in conformity with the studies of Mondal et al., (2007) and Babaknejad et al., 2015). The maintaining level of LDL and HDL in this investigation was probably linked to the HDL synthesis from LDL via the modulation of HMGCoA reductase activity by copper (Mondal et al., 2007). Contrary, copper administration to cows $(40 \mathrm{mg} / \mathrm{kg})$ had led to a cholesterol concentration increase (Engle et al., 2001) and cholesterol and LDL in rats as results of the oxidative stress (Galhardi et al., 2004).

The C. monogyna administration in both $\mathrm{L}$ and $\mathrm{F}$ groups has reduced the triglycerides levels, cholesterol, and LDL, while it raised the HDL production. In fact hawthorn given to rats at $2 \%$ of the diet was demonstrated to have a hypocholesterolemic and vasoprotective activities (Kwok et al., 2010). Researchers found that the alcoholic extract of the C. monogyna berries lowered significantly the cholesterol, triglycerides and the LDL levels (Kausar et al., 2011). Furthermore, C. monogyna could increase the receptors capacity to bind to LDL and therefore prevent the cholesterol augmentation (Kausar et al., 2011) and enhancing the cholesterol elimination to bile (Rajendran et al., 1996). Hawthorn was also been found to decrease the serum levels of cholesterol, LDL-cholesterol, and triglycerides in hypercholesterolemic and atherosclerotic animals (Chang et al., 2002). Also studies showed that hawthorn may lower the body weight as our results indicated, and it used to treat obesity and weight control (Kausar et al., 2012).

In the combined group $\mathrm{Cu} \mathrm{L}$ and $\mathrm{Cu} F$, the HDL level increased significantly, which means that the hawthorn has a beneficial effect, explained by the presence of catalytic metal ions, that increase the long and short chain cholesterol ester and phospholipids (Abuja and Albertini 2001). While LDL decreased significantly particularly HDL with high copper concentration perhaps by accelerating the LDL oxidation (Raveh et al., 2001).

\section{CONCLUSION}

The copper induced rat toxicity during thirty days has disturbed most blood parameters and lipid profile, while the co-administration of $C$. monogyna leaves and fruits extracts has led to a mitigating effect by normalizing many blood biomarkers.

\section{ACKNOWLEDGMENT}

Authors would like to thank The General Directorate of Scientific Research and Technological Development (DGRSDT) for financial support.

\section{REFERENCES :}

Abbas, B. F., Al-Jubori, W. M. K., Abdullah, A. M., Sha'aban, H. K and Mohammed, M. T. 2018. Environmental pollution with the heavy metal compound. Research Journal of Pharmacy and Technology, 11(9): 40354041. 
Abuja, P. M. and Albertini, R. 2001.Methods for monitoring oxidative stress, lipid peroxidation and oxidation resistance of lipoproteins. Clinicachimicaacta, 306(1-2): 1-17.

Ahasan, H. N., Chowdhury, M. J., Azhar, M. A. and Rafiqueuddin, A. K. M. 1994. Copper sulphatepoisoning. Tropical doctor, 24(2): 52-53.

Akomolafe, R. O., Olukiran, O. S., Imafidon, C. E., Ayannuga, O. A., Oyekunle, J. A., Akanji, B. O. and Oladele, A. A. 2014. A study of two weeks administration of copper sulphate on markers of renal function and feeding pattern of Wistarrats. African Journal of Biochemistry Research, 8(9): 158-165.

Akomolafe, R. O., Olukiran, O. S., Imafidon, C. E., Ayannuga, O. A., Oyekunle, J. A., Akanji, B. O. and Oladele, A. A. 2016. Effects of chronic copper sulphate administration on feeding pattern and markers of renal and liver functions of Wistarrats. Physiology, 26.1(89):13-19

Aksu, D. S., Didin, M. and Kayikci, F. 2012. The protective role of polyphenols on blood cells in rats exposed to lead. RevistaRomânã de Medicinã de Laborator, 20(3/4): 47-57.

Babaknejad, N., Moshtaghie, A.A., Shahanipour, K. and Bahrami, S. 2015. Effect of zinc, magnesium and copper on lipid profile as a risk factor of cardiovascular disease in male Wistarrats. Journal of Preventive Cardiology, 4(3) 692-697.

Bahorun, T., Gressier, B., Trotin, F., Brunet, C., Dine, T., Luyckx, M., Vasseur, J., Cazin, M., Cazin, J.C. and Pinkas, M. 1996. Oxygen species scavenging activity of phenolic extracts from hawthorn fresh plant organs and pharmaceutical preparations. Arzneimittelforschung, 46(11): 1086-1089.

Bahorun, T., Trotin, F., Pommery, J., Vasseur, J. and Pinkas, M. 1994. Antioxidant activities of Crataegus monogyna extracts. Planta medica, 60(04): 323-328.

Bernatonienë, J., Masteikova, R., Majienë, D., Savickas, A., Këvelaitis, E., Bernatonienë, R., Dvoráèková, K., Civinskienë, G., Lekas, R., Vitkevièius, K. and Peèiûra, R. 2008. Free radical-scavenging activities of Crataegus monogyna extracts. Medicina, 44(9): 706-12.

Beutler, E., Blume, K.G., Kaplan, J.C., Löhr, G.W., Ramot, B. and Valentine, W.N. 1977. International comittee for standardisation in haematology: recommended methods for red cell enzyme analysis. British Journal of Haematology, 35: 331-340

Bucolo, G. and David, H. 1973. Quantitative determination of serum triglycerides by the use of enzymes. Clinical chemistry, 19(5): 476-482.

Burkhead, J. L. and Lutsenko, S. 2013. The role of copper as a modifier of lipid metabolism.In Lipid metabolism. IntechOpen.

Chambers, A., Krewski, D., Birkett, N., Plunkett, L., Hertzberg, R., Danzeisen, R., Jonesk, P., Keenl, C. L., Meekm, B., Schoenyn, R. and Slob, W. 2010. An exposure-response curve for copper excess and deficiency. Journal of Toxicology and Environmental Health, Part B, 13(7-8): 546-578. .

Chang, Q., Zuo, Z., Harrison, F. and Chow, M. S. S. 2002. Hawthorn. The Journal of Clinical Pharmacology, 42(6), 605-612.

DES, N. 2013. Copper: Health information summary. Concord, NH, USA: New Hampshire Department of Environmental Services.

Eck, P. C. and Wilson, L. 1989. Copper toxicity. Eck Institute of Applied Nutrition and Bioenergetics Ltd, 1-16.

Engle, T. E., Fellner, V. and Spears, J. W. 2001. Copper status, serum cholesterol, and milk fatty acid profile in Holstein cows fed varying concentrations of copper. Journal of Dairy Science, 84(10): 2308-2313.

Fong, H.H. and Bauman, J. L. 2002. Hawthorn. Journal of Cardiovascular Nursing, 16(4), 1-8.

Friedewald, William, T., Robert, I. Levy, and Donald, S. Fredrickson. 1972. Estimation of the concentration of low-density lipoprotein cholesterol in plasma, without use of the preparative ultracentrifuge. Clinical Chemistry, 18 (6):499-502.

Galhardi, C. M., Diniz, Y. S., Faine, L. A., Rodrigues, H. G., Burneiko, R. C., Ribas, B. O. and Novelli, E. L. 2004. Toxicity of copper 
intake: lipid profile, oxidative stress and susceptibility to renal dysfunction. Food and chemical toxicology, 42(12): 2053-2060.

Ganong, W.F. 2009. Review of Medical Physiology, 23rd ed, Mc Grow Hill, New York, pp 65

Grove, T.H. 1979. Effect of reagent $\mathrm{pH}$ on Determination of HDL Cholesterol by precipitation with Sodium Phosphotungstatemagnesium. Clinical Chemistry, 25:560.

Jalali, A. S., Hasanzadeh, S. and Malekinejad, H. 2012. Crataegus monogyna aqueous extract ameliorates cyclophosphamide-induced toxicity in rat testis: stereological evidences. Acta MedicaIranica, 50(1):1-8.

James, L. P., Stowe, C. D. and Argao, E. R. I. C. 1999. Gastric injury following copper sulfate ingestion. Pediatric emergency care, 15(6): 429-431.

Joshi, P. K., Bose, M. and Harish, D. 2002. Haematological changes in the blood of Clariasbatrachus exposed to mercuric chloride. Journal of Ecotoxicology \& Environmental Monitoring, 12(2): 119-122.

Kausar, S., Zaheer, Z. and Saqib, M. 2012. Role of Crataegus (Hawthorn) Extract on Obesity in Hyperlipidemic Albino Rats. Pakistan Journal of Medical and Health Sciences, 6(1):100-103.

Kausar, S., Zaheer, Z., Saqib, M. and Zia, B. U. S. H. R. A. 2011. The effect of Crataegus (Hawthorn) extract alone and in combination with simvastatin on serum lipid profile in hyperlipidemic albino rats. Biomedica, 27(2): 140-7.

Keser, S., Celik, S., Turkoglu, S., Yilmaz, Ö and Turkoglu, I. 2014. The investigation of some bioactive compounds and antioxidant properties of hawthorn (Crataegus monogyna subsp. monogyna Jacq). Journal of intercultural ethnopharmacology, 3(2): 5155.

Kumar, A., Gupta, T., Berzsenyi, S. and Giangrande, A. 2015. N-cadherin negatively regulates collective Drosophila glial migration through actin cytoskeleton remodeling. Journal of Cells Sciences, 128(5): 900-912.

Kuo, S. M., Leavitt, P. S. and Lin, C. P. 1998. Dietary flavonoids interact with trace metals and affect metallothionein level in human intestinal cells. Biological Trace Element Research, 62(3): 135-153.

Kwok, C. Y., Wong, C. N. Y., Yau, M. Y. C., Yu, P. H. F., Au, A. L. S., Poon, C. C. W., Sai-Wang. S., Tsz-Y.L., Yiu-Wa, K and Chan, S. W. 2010. Consumption of dried fruit of Crataegus pinnatifida (hawthorn) suppresses high-cholesterol diet-induced hypercholesterolemia in rats. Journal of Functional Foods, 2(3): 179-186.

Liu, H., Liu, J., Lv, Z., Yang, W., Zhang, C., Chen, D. and Jiao, Z. 2019. Effect of dehydration techniques on bioactive compounds in hawthorn slices and their correlations with antioxidant properties. Journal of food science and technology, 56(5): 2446-2457.

Mondal, M. K., Das, T. K., Biswas, P., Samanta, C. C. and Bairagi, B. 2007. Influence of dietary inorganic and organic copper salt and level of soybean oil on plasma lipids, metabolites and mineral balance of broiler chickens. Animal feed science and technology, 139(3-4): 212-233.

Naito, H.K.1984. High-density lipoprotein (HDL) cholesterol.Kaplan A et al. Clinical Chemistry.The C.V. Mosby Co. St Louis. Toronto. Princeton; 1207-1213 and437.

Nandi, P. and Ghosh, S. N. 2016. Effect of medicinal plants as intercrop on plant and soil of Mosambi sweet orange gown in laterite oil. International Journal of Minor Fruits, Medicinal and Aromatic Plants, 2(2): 11-13.

Nelson, L.S. 2002. Copper. In: Goldfrank LR, Flomenbaum NE, Lewin NA, editors. Goldfrankstoxicologic emergencies 7th ed, McGraw-Hill: New York, 1262-71.

Oldenquist, G. and Salem, M. 1999. Parenteral copper sulfate poisoning causing acute renal failure. Nephrology, dialysis, transplantation: official publication of the European Dialysis and Transplant Association-European Renal Association, 14(2): 441-443.

Ozcelik, D. and Uzun, H. 2009. Copper intoxication; antioxidant defenses and oxidative damage in rat brain. Biological trace element research, 127(1), 45-52.

Parmar, P., Limson, J., Nyokong, T. and Daya, S. 2002. Melatonin protects against copper 
mediated free radical damage. Journal of pineal research, 32(4): 237-242.

Pmila, D., Subbaiyan, P. S. and Ramaswamy, M. 1991. Toxic effect of chromium and cobalt on sarotherodonmossambicus. Indian Journal of Environmental Health, 33: 218224.

Quamar, S., Kumar, J., Mishra, A. and Flora, S. J. S. 2019. Oxidative stress and neurobehavioural changes in rats following copper exposure and their response to MiADMSA and d-penicillamine. Toxicology Research and Application, 3:https://doi.org/10.1177/ 2397847319844782

Rajendran, S., Deepalakshmi, P. D., Parasakthy, K., Devaraj, H. and Devaraj, S. N. 1996. Effect of tincture of Crataegus on the LDL-receptor activity of hepatic plasma membrane of rats fed an atherogenic diet. Atherosclerosis, 123(1-2): 235-241.

Raveh, O., Pinchuk, I., Fainaru, M. and Lichtenberg, D. 2001. Kinetics of lipid peroxidation in mixtures of HDL and LDL, mutual effects. Free Radical Biology and Medicine, 31(11): 1486-1497.

Rice-Evans, C. 2004. Flavonoids and isoflavones: absorption, metabolism, and bioactivity. Free Radical Biology and Medicine, 7(36): 827828.

Samanta, B., Ghosh, P. R., Biswas, A. and Das, S. K. 2011.The effects of copper supplementation on the performance and hematological parameters of broiler chickens.
Asian-Australasian Journal of Animal Sciences, 24(7): 1001-1006.

Saravu, K., Jose, J., Bhat, M. N., Jimmy, B. and Shastry, B. A. 2007. Acute ingestion of copper sulphate: A review on its clinical manifestations and management. Indian Journal of Critical Care Medicine, 11(2): 7480.

Tiwari, M. K., Leinisch, F., Sahin, C., Møller, I. M., Otzen, D. E., Davies, M. J. and Bjerrum, M. J. 2018. Early events in copper-ion catalyzed oxidation of á-synuclein. Free Radical Biology and Medicine, 121, 38-50.

Witeska, M. and Wakulska, M. 2007.The effects of heavy metals on common carp white blood cells in vitro. Alternatives to Laboratory Animals, 35(1): 87-92.

Wuolikainen, A., Acimovic, J., Lövgren-Sandblom, A., Parini, P., Andersen, P. M and Björkhem, I. 2014.Cholesterol, oxysterol, triglyceride, and coenzyme Q homeostasis in ALS. Evidence against the hypothesis that elevated 27-hydroxycholesterol is a pathogenic factor. PloS one, 9(11), e113619.

Yao, M., Ritchie, H. E. and Brown-Woodman, P. D. 2008. A reproductive screening test of hawthorn. Journal of ethnopharmacology, 118(1): 127-132. (H32).

Zapfe, G. J. 2001. Clinical efficacy of Crataegus extract WS ${ }^{\circledR} 1442$ in congestive heart failure NYHA class II. Phytomedicine, 8(4): 262266. 